
$\$$ Research Square
Preprints are preliminary reports that have not undergone peer review.
They should not be considered conclusive, used to inform clinical practice, or referenced by the media as validated information.

\title{
Biofilm Growth By Listeria Monocytogenes On Stainless Steel and Expression of Biofilm-Related Genes Under Stressing Conditions
}

Danilo Augusto Lopes da Silva

UFV: Universidade Federal de Vicosa

Rafaela de Melo Tavares

UFV: Universidade Federal de Vicosa

Anderson Carlos Camargo

UFV: Universidade Federal de Vicosa

Ricardo Seiti Yamatogi

UFV: Universidade Federal de Vicosa

Elaine Cristina Pereira De Martinis

USP: Universidade de Sao Paulo

Luis Augusto Nero ( $\square$ nero@ufv.br)

Universidade Federal de Viçosa https://orcid.org/0000-0002-4954-5824

\section{Research Article}

Keywords: Listeria monocytogenes, biofilm, stainless steel, stressing conditions, gene expression

Posted Date: April 13th, 2021

DOI: https://doi.org/10.21203/rs.3.rs-408423/v1

License: (c) (i) This work is licensed under a Creative Commons Attribution 4.0 International License. Read Full License 


\section{Abstract}

This research was carried out to assess the ability of L. monocytogenes for adhesion and growth in biofilm on stainless steel coupons under different stressing conditions ( $\mathrm{NaCl}$, curing salts and quaternary ammonium compounds - $\mathrm{QAC}$ ), besides determining the expression of different genes involved in biofilm formation and stress response. Results from crystal violet assay revealed that one isolate carrying a premature stop codon (PMSC) in agrC gene formed high-density biofilms in the presence of QAC or cure salts (7.5\% and $10 \%)$. Reverse Transcriptase-qPCR results revealed that isolates of $L$. monocytogenes lineages I and II presented differences in transcriptional profile of genes related to biofilm formation and adaptation to environmental conditions. In conclusion, our results demonstrated how L. monocytogenes can survive, multiply and form biofilm under adverse conditions related to food processing environments. Differences in transcriptional expression were observed, highlighting the role of regulatory gene networks for particular serotypes under different stress responses.

\section{Introduction}

Listeria monocytogenes is the causative agent of listeriosis, a foodborne disease that affects mainly children, pregnant women, the elderly and immunocompromised individuals (Radoshevich and Cossart 2018). Due to its capacity to adhere and to form biofilms, L. monocytogenes can colonize food processing facilities and often persist in this environment for years, leading to cross contamination of foodstuffs (Møretrø and Langsrud 2004; RodríguezMelcón et al. 2019). L. monocytogenes can adhere and form biofilms on different materials, such as stainless steel, glass and polymers, favoring its environmental persistence (Carpentier and Cerf 2011). Nevertheless, L. monocytogenes is also known for other features that contributes for its persistence in the food processing environments, such as tolerance to disinfectants, to cold storage temperatures and to high salt concentrations (Ryan et al. 2010; Belessi et al. 2011; Pieta et al. 2014; Lee et al. 2017).

Several genes may regulate biofilm development, allowing bacterial survival under adverse environmental conditions (Keeney et al. 2018). Despite being also probably related to $L$. monocytogenes pathogenicity, the molecular mechanisms responsible for the expression of biofilm related genes are not completely understood (Lemon et al. 2007; Bonsaglia et al. 2014; Nowak et al. 2017). However, the increasing use of advanced molecular tools, like whole genome sequencing (WGS), is allowing deeper studies on L. monocytogenes genomics and the proper understanding of the relatedness between persistent and transient strains at sub species level (Jagadeesan et al. 2019).

Here, we aimed to assess the potential for adhesion and biofilm formation under stressing conditions by persistent strains of $L$. monocytogenes from lineages I (serotype 1/2b) and II (serotype 1/2c), as well as to quantify the expression of selected genes relevant for biofilm formation and stress response.

\section{Material And Methods}

\section{Bacterial strains}

Four L. monocytogenes isolates were selected for this study, based on their characteristics previously described by Camargo et al. (2019) and presented in Table 1. These isolates presented genes enrolled in biofilm formation and stress response (flaA, agrB, agrC, Imo0444, Imo0445 and Imo0446), previously identified by Whole Genome Sequencing , according to data available at GenBank (National Center for Biotechnology Information, Bethesda, MD, USA, Supplementary Table 1).

Table 1

Origin description and genotypes of isolates used in the present study, genotyped previously by Camargo et al., (2019).

\begin{tabular}{|c|c|c|c|c|c|c|c|c|c|c|c|c|}
\hline Isolate & Year & State & $\begin{array}{l}\text { Source } \\
\text { type }\end{array}$ & $\begin{array}{l}\text { Sample } \\
\text { type }\end{array}$ & & Serotype & $\begin{array}{l}\text { PCR- } \\
\text { serogroup }^{3}\end{array}$ & Lineage & $\begin{array}{l}\text { CC } \\
(M L S T)^{4}\end{array}$ & $\begin{array}{l}\text { ST } \\
(\mathrm{MLST})^{4}\end{array}$ & $\begin{array}{l}\text { SL } \\
(\text { cgMLST) }\end{array}$ & $\begin{array}{l}\text { CT } \\
(\mathrm{cgMLST})^{5}\end{array}$ \\
\hline 19 & 2009 & $\mathrm{MG}^{1}$ & $\mathrm{PE}^{2}$ & $\begin{array}{l}\text { Meat } \\
\text { handlers }\end{array}$ & $\begin{array}{l}\text { Before } \\
\text { processing }\end{array}$ & $1 / 2 c$ & Illc & II & $\mathrm{CC} 9$ & ST9 & SL9 & CT4420 \\
\hline 508 & 2012 & $\mathrm{MG}^{1}$ & Food & $\begin{array}{l}\text { Raw } \\
\text { beef }\end{array}$ & Refrigerated & $1 / 2 c$ & IIc & II & $\mathrm{CC} 9$ & ST9 & SL9 & CT4420 \\
\hline $\begin{array}{l}\text { CLIST } \\
441\end{array}$ & 2010 & MT & Food & $\begin{array}{l}\text { Raw } \\
\text { beef }\end{array}$ & Refrigerated & $1 / 2 b$ & Illb & I & $\mathrm{CC} 3$ & ST3 & SL3 & CT4447 \\
\hline 7 & 2009 & MG & Food & $\begin{array}{l}\text { Raw } \\
\text { beef }\end{array}$ & Refrigerated & $1 / 2 b$ & Illb & I & $\mathrm{CC} 3$ & ST3 & SL3 & СТ4448 \\
\hline
\end{tabular}

MG, Minas Gerais; MT, Mato Grosso;

${ }^{1}$ Recovered from the same food processing facility.

${ }^{2}$ Production environment.

${ }^{3}$ According to Doumith et al., (2004) and Leclercq et al., (2011).

${ }^{4}$ Clonal complex (CC) and sequence type (ST) defined according to Ragon et al., (2008).

${ }^{5}$ Sublineage (SL) and cgMLST type (CT) defined according to Moura et al., (2016). 
L. monocytogenes isolates (Table 1) were evaluated for adhesion and biofilm formation under stressing conditions on stainless steel microtiter plates. The stressing conditions selected for this study were: (i) curing salts $(5,7.5$ and $10 \%, \mathrm{w} / \mathrm{v}$ ); (ii) $\mathrm{NaCl}(5,7.5$ and $10 \%$, w/v), and (iii) quaternary ammonium compounds (QAC) at the concentration of 1:1,024, which corresponded to the Minimum Inhibitory Concentration (MIC), according to Silva et al. (2020).

To test the effect of QAC on adhesion of L. monocytogenes, aliquots of $20 \mu \mathrm{L}\left(10^{9}\right.$ cells $\left./ \mathrm{mL}\right)$ of the cultures were transferred to wells of a stainless-steel microtiter plate containing $130 \mu \mathrm{L}$ of Brain Heart Infusion broth (BHI, Oxoid Ltd., Basingstoke, UK) and $30 \mu \mathrm{L}$ of a QAC based sanitizer at 1:1,024 (Kalyclean S 370, Kalykim, Alvorada, RS, Brazil). Also, $20 \mu \mathrm{L}$ aliquots of each L. monocytogenes culture were transferred to wells containing $160 \mu \mathrm{L}$ of BHI (0xoid) supplemented with curing salts (Exato, São Paulo, SP, Brazil) at three different concentrations (5, 7.5 and 10\%, w/v) and sodium chloride (Vetec, Rio de Janeiro, RJ, Brazil), also with varying concentrations (5, 7.5 and $10 \%, w / v)$. Plates were incubated at $37^{\circ} \mathrm{C}$ for $72 \mathrm{~h}$, under constant agitation at $15 \mathrm{rpm}$. After incubation, the broths were discarded, and the wells were washed three times with Phosphate Buffered Saline (PBS, pH 7.2) to remove non-adhered cells. To predict the biofilm production, the crystal violet method was employed as previously described by Silva et al. (2017).

Additionally, assays were carried out to enumerate viable cells of L. monocytogenes isolates grown on stainless steel microtiter plates, either in the presence of 7.5\% curing salts (for lineage I) and QAC at 1:1,024 (MIC, for lineage II). Isolates, curing salts and QAC were distributed in stainless-steel microtiter plates, and incubated at $37^{\circ} \mathrm{C}$ for $72 \mathrm{~h}$, under constant agitation at $15 \mathrm{rpm}$. Then, non-adhered cells were removed by washing with PBS, and the adhered cells were removed with $200 \mu \mathrm{L}$ of PBS added with Tween 80 at $1 \%$ (v/v, Dinâmica, Indaiatuba, SP, Brazil). Tenfold dilutions of the biofilm suspensions were done in PBS, drop plated $(10 \mu \mathrm{L})$ on $\mathrm{BHI}$ agar (Oxoid) and incubated at $37^{\circ} \mathrm{C}$ for $24 \mathrm{~h}$, according to Herigstad et al. (2001), with modifications. The assays were performed as biological triplicates. Controls were prepared by growing L. monocytogenes in biofilms in the absence of curing salts and QAC. The results were expressed as colony forming units (CFU) per $\mathrm{cm}^{2}$, for sessile cells. To calculate significant differences between the groups it was applied analysis of variance ( $p<0.05$ ) using the software XLSat 2010.2.03 (Addinsoft, New York, NY, USA).

Besides, L. monocytogenes biofilms were grown on stainless steel coupons (AISI 304, $3.8 \mathrm{~cm}^{2}$ ) in the presence of curing salts (7.5\%) and QAC (MIC, 1:1,024) at $37^{\circ} \mathrm{C}$ for $72 \mathrm{~h}$, under constant agitation of $15 \mathrm{rpm}$. Prior to inoculation, the coupons were cleaned and prepared according to Winkelströter et al. (2011) and placed in 24 wells polystyrene microtiter plates (TPP, Trasadingen, Switzerland). To enumerate the L. monocytogenes cells attached to the coupons, each coupon was rinsed three times with PBS to eliminate non-adhered cells, transferred to test tubes containing $2 \mathrm{~mL}$ of PBS added with Tween 80 at $1 \%$ ( $\mathrm{v} / \mathrm{v}$ ), treated for $2 \mathrm{~min}$ in ultrasound bath (50-60 kHz) and vortexed for $1 \mathrm{~min}$ according to Leriche and Carpentier (1995), with modifications. Tenfold dilutions of the biofilm suspensions were done in PBS, drop plated $(10 \mu \mathrm{L})$ on $\mathrm{BHI}$ agar (Oxoid) and incubated at $37^{\circ} \mathrm{C}$ for $24 \mathrm{~h}$, according to Herigstad et al. (2001). The assays were performed as biological triplicates and included the appropriate controls (wells without curing salts and QAC). To consider a biofilm was formed, the minimum of $10^{3}$ adhered cells per $\mathrm{cm}^{2}$ was required (Minei et al. 2008; Winkelströter and De Martinis 2015). Results were expressed as CFU per $\mathrm{cm}^{2}$, for sessile cells, with $2 \mathrm{~mL}$ of the homogenate corresponding $3.8 \mathrm{~cm}^{2}$. Analysis of variance $(p<0.05)$ was applied to calculate the differences between groups using the program XLSat 2010.2.03 (Addinsoft).

\section{Gene expression prediction by qPCR}

Taking into consideration L. monocytogenes lineages I and II can present different tolerance to various stresses (Van Der Veen et al. 2008) and phenotypic results from preliminary assays, selected biofilms grown on stainless steel coupons were recovered and RT-qPCR was performed to examine the transcriptional profile of different genes important for biofilm growth and adaptation to environmental conditions ( $f$ la $A$, agrB and agrC) as well as stressrelated genes (Imo0444, Imo0445 and Imo0446).

Two independent biological replicates were performed for the gene expression assays, using the protocol described above for biofilm formation by $L$. monocytogenes on stainless steel coupons for isolates of lineage I (CLIST 441 and 7) in the presence of $7.5 \%$ curing salts, and isolates of lineage II (508 and 19) in the presence of the QAC at 1:1,024 (MIC). Biofilms were grown at $37^{\circ} \mathrm{C}$ or $72 \mathrm{~h}$.

RNA extraction was performed using RNeasy Mini Kit (Qiagen, Hilden, Germany) according to the manufacturer's protocols. The extracted RNA was treated with RQ1 RNase-Free DNase (Promega, Madison, USA) and cDNA synthesis was performed by the Go Script Reverse Transcription System (Promega) according to the manufacturer's instructions. The cDNA was used to perform the predictive expression of the genes selected (flaA, agrB, agrC, Imo0444, Imo0445 and Imo0446). The primers used in this study are shown in Table 2(Autret et al. 2003; Ryan et al. 2010; Pieta et al. 2014; Miranda et al. 2018). All qPCR amplifications were performed with final volume of $20 \mu \mathrm{L}$, using10 $\mu \mathrm{L}$ of GoTaq® qPCR Master (Promega, Madison, USA), $200 \mathrm{nMol}$ of each primer, $2 \mu \mathrm{L}$ of cDNA and ultrapure RNase free water to complete the final volume. The conditions for PCR reaction comprised an initial denaturation step at $95^{\circ} \mathrm{C}$ for 2 min and 45 cycles of $95^{\circ} \mathrm{C}$ for $15 \mathrm{~s}$ and $60^{\circ} \mathrm{C}$ for $60 \mathrm{~s}$. The dissociation curve program was followed to obtain the melting curve of the target analyzed. 
Table 2

Panel of genes related to the biofilm formation and environmental stress resistance evaluated by qPCR assays.

\begin{tabular}{|c|c|c|c|c|}
\hline Gene & Reference & Sequence & $\begin{array}{l}\text { Product } \\
\text { lenght }\end{array}$ & Function \\
\hline \multirow[t]{2}{*}{$r p / D 1$} & \multirow{2}{*}{$\begin{array}{l}\text { Miranda et al., } \\
(2017)\end{array}$} & F: 5-GTCCCTTGACGTAGGGATGC-3 & \multirow[t]{2}{*}{113 bp } & \multirow[t]{2}{*}{ Normalizer } \\
\hline & & R: 5-GGAACAAACGCTGGCGAAAT-3 & & \\
\hline \multirow[t]{2}{*}{$f l a A$} & \multirow[t]{2}{*}{ Pieta et al., (2014) } & F: 5-GTAAGCATCCAAGCGTCTGA-3 & \multirow[t]{2}{*}{148 bp } & \multirow[t]{2}{*}{ Influences biofilm formation } \\
\hline & & R: 5-AAGAATCAGCATCAGCAACG-3 & & \\
\hline \multirow[t]{2}{*}{$\operatorname{agr} B$} & \multirow[t]{2}{*}{ Autret et al., (2003) } & $\begin{array}{l}\text { F: 5-AGGTACATTTGGATTTATACTGCTCAAC- } \\
3\end{array}$ & \multirow[t]{2}{*}{81 bp } & \multirow[t]{2}{*}{ Adaptation to environmental conditions } \\
\hline & & R: 5-TCTTCACCGATTAAAGGCAAACT-3 & & \\
\hline \multirow[t]{2}{*}{$\operatorname{agrc}$} & \multirow[t]{2}{*}{ Autret et al., (2003) } & $\begin{array}{l}\text { F: 5- } \\
\text { ATTGACAAGATTTCGATGGATAGTATAGATT- } \\
3\end{array}$ & \multirow[t]{2}{*}{$88 \mathrm{bp}$} & \multirow[t]{2}{*}{ Adaptation to environmental conditions } \\
\hline & & R: 5-CACAAGTTAACGCCGCTTCA-3 & & \\
\hline \multirow[t]{2}{*}{ SSI-1 Imo 0444} & \multirow[t]{2}{*}{ Ryan et al., (2010) } & F: 5-CATCTGCTCTTGTCGGTTCA-3 & \multirow[t]{2}{*}{$85 \mathrm{bp}$} & \multirow{2}{*}{$\begin{array}{l}\text { Adaptation to low } \mathrm{pH} \text { and high salt } \\
\text { concentration }\end{array}$} \\
\hline & & R: 5-CCGACACCATTCTCAAGGTT-3 & & \\
\hline \multirow[t]{2}{*}{ SSI-1 Imo 0445} & \multirow[t]{2}{*}{ Ryan et al., (2010) } & F: 5-TAGACGAGCTTTGGAACCTC-3 & \multirow[t]{2}{*}{$99 \mathrm{bp}$} & \multirow{2}{*}{$\begin{array}{l}\text { Adaptation to low } \mathrm{pH} \text { and high salt } \\
\text { concentration }\end{array}$} \\
\hline & & R: 5-GGTATCGGGGCCATTTCTTC-3 & & \\
\hline \multirow{2}{*}{$\begin{array}{l}\text { SSI-1 Imo } 0446 \\
(p v a)\end{array}$} & \multirow[t]{2}{*}{ Ryan et al., (2010) } & F: 5-TTGCGCAACGATTAAAGATG-3 & \multirow[t]{2}{*}{$131 \mathrm{bp}$} & \multirow{2}{*}{$\begin{array}{l}\text { Adaptation to low } \mathrm{pH} \text { and high salt } \\
\text { concentration }\end{array}$} \\
\hline & & R: 5-TCACTACACAACGCССАCTC-3 & & \\
\hline
\end{tabular}

\section{Results}

Absorbance values obtained for adhesion assays on stainless steel microtiter plates showed that in the presence of QAC or curing salts (7.5\%, and $10 \%)$ the isolate CLIST 441 (serotype 1/2b) formed higher-density biofilms, when compared to the other isolates tested (Fig. 1). Data also revealed curing salts and sodium chloride treatments did not cause major changes in adherence pattern of isolates 7 (serotype 1/2b) and 508 (serotype 1/2c), while these treatments reduced biofilm production by isolate 19 (serotype 1/2c) (Fig. 1).

Based on absorbance values recorded by crystal violet assay, specific treatments were employed in further testing, where the isolates 7 and CLIST 441 (lineage I, serotype 1/2b) were exposed to cure salts while isolates 19 and 508 (lineage II, serotype 1/2c) were exposed to QAC treatment, on stainless steel microtiter plates and coupons. The results revealed a similar behavior, where the treatments reduced the viable attached cells significantly (Figs. 2 and 3 ), being QAC treatment more efficient.

To examine the transcriptional correlation between the isolates studied, gene expression was quantified by RT-qPCR. The results showed that long term persistent isolates from lineage II (508 and 19) presented transcripts for all genes evaluated (flaA, agrB, agrC, Imo0444, Imo0445, and Imo0446), in the presence or in the absence of QAC (Table 3). On the other hand, isolates 441 and 7 (lineage I) selected for biofilm formation on stainless steel coupons in the presence of $7.5 \%$ cure salts, did not present transcripts for fla $A$ and $I m o 0446$ (Table 3).

Table 3. Panel of gene expression prediction by qPCR, for the different genes and two distinct treatments. 


\begin{tabular}{|c|c|c|c|c|c|c|c|c|c|}
\hline Treatment & Isolate & $\mathrm{UFC} / \mathrm{cm}^{2}$ & $\operatorname{rlp} D 1$ & flaA & $a g r B$ & $a g r C$ & Lmo0444 & $\operatorname{lmo} 0445$ & $\operatorname{lmo} 0446$ \\
\hline BHI & CLIST 441 & $2.6 \times 10^{5}$ & & & & & & & \\
\hline BHI & CLIST 441 & $9.7 \times 10^{5}$ & & & & & & & \\
\hline $\mathrm{BHI}+$ Curing salt & CLIST 441 & $2.2 \times 10^{3}$ & & & & & & & \\
\hline BHI + Curing salt & CLIST 441 & $1.1 \times 10^{4}$ & & & & & & & \\
\hline BHI & 7 & $1.1 \times 10^{5}$ & & & & & & & \\
\hline BHI & 7 & $8.6 \times 10^{4}$ & & & & & & & \\
\hline BHI + Curing salt & 7 & $5.2 \times 10^{3}$ & & & & & & & \\
\hline BHI + Curing salt & 7 & $2.8 \times 10^{3}$ & & & & & & & \\
\hline BHI & 508 & $3.6 \times 10^{6}$ & & & & & & & \\
\hline BHI & 508 & $3.4 \times 10^{6}$ & & & & & & & \\
\hline $\mathrm{BHI}+\mathrm{QAC}$ & 508 & $2.6 \times 10^{2}$ & & & & & & & \\
\hline $\mathrm{BHI}+\mathrm{QAC}$ & 508 & $4.2 \times 10^{2}$ & & & & & & & \\
\hline BHI & 19 & $3.6 \times 10^{5}$ & & & & & & & \\
\hline BHI & 19 & $1.4 \times 10^{6}$ & & & & & & & \\
\hline $\mathrm{BHI}+\mathrm{QAC}$ & 19 & $7.1 \times 10^{2}$ & & & & & & & \\
\hline $\mathrm{BHI}+\mathrm{QAC}$ & 19 & $1 \times 10^{2}$ & & & & & & & \\
\hline
\end{tabular}

- Positive gene expression a gene expression not detected, $r l p D l$ : normalizer.

\section{Discussion}

In addition to strain specific properties, initial cell attachment and biofilm formation can be influenced by environmental conditions (Katsikogianni et al. 2004) and extrinsic factors, including the physiochemical characteristics of the surface material(Van Houdt and Michiels 2010). It is well known that $L$. monocytogenes persistence in food processing facilities is usually associated with biofilm formation and the capacity to resist sanitization procedures (Poimenidou et al. 2016; Møretrø et al. 2017).

The results of crystal violet assays from this research (Fig. 1) revealed L. monocytogenes CLIST 441 (serotype 1/2b) formed high-density biofilms in the presence of QAC or curing salts (7.5\%, and 10\%). This isolate carries a PMSC mutation in agrC gene, but it remains unclear if this characteristic influenced biofilm development, since the results of crystal violet assays refer to the quantification of total biomass, and not only microbial cells. Some studies have already reported increased tolerance to QAC among persistent L. monocytogenes strains (Ortiz et al. 2014; Møretrø et al. 2017). Moreover, L. monocytogenes can differ in ability to grow and form biofilm in different stress conditions between lineages and serotypes (Orsi et al. 2011). Lineage II strains present a significant association with resistance to QAC and are more commonly found in food processing environments, compared to lineage I strains (Mereghetti et al. 2000; Ferreira et al. 2014; Poimenidou et al. 2016). In agreement with a previous research (Silva et al. 2020), long term persistent strains tested in this study (isolates 19 and 508, from Lineage II) were able to survive and to form biofilms on stainless steel microtiter plates and coupons in the presence of QAC at MIC (Fig. 3).

Regulatory networks ensure proper regulation of biofilm formation under different environmental condition and nutrient sources, and it can be studied to investigate the connection of different serotypes and different stress responses(Katsikogianni et al. 2004; Ouyang et al. 2012). Here, the transcriptional profile of six different genes (agrB, andagrC Imo0444, Imo0445, and Imo0446) enrolled in stress responses, adaptation to environmental conditions and biofilm formation were quantified by analyzing bacterial cells recovered from the biofilms grown on stainless steel coupons. Transcriptional expression of the agr operon (agrBDCA) was assessed through RT-qPCR for two genes of the agr system (agrB and agrC) and for each gene the results showed differences even for the same treatment, where agrC was not expressed in strain 19 (serotype 1/2c) in one of the treatments (QAC). The agr system plays an important role in adaptation and biofilm formation by L. monocytogenes(Riedel et al. 2009). Although the agr system is transcribed as a single messenger, it can present differential expression of the agrgenes depending on different growth phases and environmental conditions, due to posttranscriptional processes, such as cleavage and degradation of agrC transcripts (Rieu et al. 2007).

Imo0446 is part of a five-gene island (Imo0444 - Imo0448) previously associated to growth of L. monocytogenes under low pH and high salt concentrations, that favors survival of certain strains in food associated environments(Ryan et al. 2010). Also, Imo0446 is predicted to encode a bile tolerance locus (Begley et al. 2005). The absence of Imo0446 transcripts in the isolates from lineage I (7 and CLIST 441) was not expected, as the island is self-regulated by the product of Imo0445, a putative transcriptional regulator, that presented normal expression (Table 3).

L. monocytogenes gene flaA encodes the flagellin protein FlaA (Dons et al. 1992), previously associated with growth at low temperatures and biofilm formation on abiotic surfaces (Liu et al. 2002; Lemon et al. 2007). Under static conditions, flagellum-mediated motility has been linked to initial surface attachment and biofilm development (Ouyang et al. 2012). Liu et al. (2002) described that regulation of flaA is increased specially under low temperatures, with low levels of transcripts detected in bacteria grown at $37^{\circ} \mathrm{C}$. Gene expression patterns associated to biofilm formation can vary when different stresses are applied, however further studies need to examine the correlation between serotype and biofilm formation. 
To conclude, our results highlight the ability of the selected L. monocytogenes isolates to survive in food processing facilities under stress conditions and persist in such environments, leading to food contamination. The difference of genetic expression between groups, allowed to identify which genes may assist survival and biofilm formation under stress conditions commonly encountered by L. monocytogenes in food processing environments and foodstuff.

\section{Declarations}

\section{Acknowledgements}

The authors are thankful to Coordenação de Aperfeiçoamento de Pessoal de Nível Superior (CAPES, Brasília, DF, Brazil), Conselho Nacional de Desenvolvimento Científico e Tecnológico (CNPq, Brasília, DF, Brazil) and Fundação de Amparo à Pesquisa do Estado de Minas Gerais (FAPEMIG, Belo Horizonte, MG, Brazil) for financial support.

\section{Conflict of Interest}

The authors declare that they have no conflict of interest.

\section{References}

Autret N, Raynaud C, Dubail I, et al (2003) Identification of the agr locus of Listeria monocytogenes: role in bacterial virulence. Infect Immun 71:4463-4471. https://doi.org/10.1128/IAI.71.8.4463-4471.2003

Begley M, Sleator RD, Gahan CGM, Hill C (2005) Contribution of three bile-associated loci, $b s h$, $p v a$, and $b t / B$, to gastrointestinal persistence and bile tolerance of Listeria monocytogenes. Infect Immun 73:894-904. https://doi.org/10.1128/IAI.73.2.894-904.2005

Belessi CEA, Gounadaki AS, Psomas AN, Skandamis PN (2011) Efficiency of different sanitation methods on Listeria monocytogenes biofilms formed under various environmental conditions. Int J Food Microbiol 145:. https://doi.org/10.1016/j.ijfoodmicro.2010.10.020

Bonsaglia ECR, Silva NCC, Fernades Júnior A, et al (2014) Production of biofilm by Listeria monocytogenes in different materials and temperatures. Food Control 35:386-391. https://doi.org/10.1016/j.foodcont.2013.07.023

Camargo AC, Moura A, Avillan J, et al (2019) Whole-genome sequencing reveals Listeria monocytogenes diversity and allows identification of long-term persistent strains in Brazil. Environ Microbiol 21:. https://doi.org/10.1111/1462-2920.14726

Carpentier B, Cerf O (2011) Review - Persistence of Listeria monocytogenes in food industry equipment and premises. Int. J. Food Microbiol. 145:1-8

Dons L, Rasmussen OF, Olsen JE (1992) Cloning and characterization of a gene encoding flagellin of Listeria monocytogenes. Mol Microbiol 6:2919-2929. https://doi.org/10.1111/j.1365-2958.1992.tb01751.x

Ferreira V, Wiedmann M, Teixeira P, Stasiewicz MJ (2014) Listeria monocytogenes persistence in food-associated environments: Epidemiology, strain characteristics, and implications for public health. J. Food Prot. 77:150-170

Herigstad B, Hamilton M, Heersink J (2001) How to optimize the drop plate method for enumerating bacteria. J Microbiol Methods 44:121-129. https://doi.org/10.1016/S0167-7012(00)00241-4

Jagadeesan B, Baert L, Wiedmann M, Orsi RH (2019) Comparative analysis of tools and approaches for source tracking Listeria monocytogenes in a food facility using whole-genome sequence data. Front Microbiol 10:. https://doi.org/10.3389/fmicb.2019.00947

Katsikogianni M, Missirlis YF, Harris L, Douglas J (2004) Concise review of mechanisms of bacterial adhesion to biomaterials and of techniques used in estimating bacteria-material interactions. Eur. Cells Mater. 8:37-57

Keeney K, Trmcic A, Zhu Z, et al (2018) Stress survival islet 1 contributes to serotype-specific differences in biofilm formation in Listeria monocytogenes . Lett Appl Microbiol 67:530-536. https://doi.org/10.1111/lam.13072

Lee BH, Hébraud M, Bernardi T (2017) Increased adhesion of Listeria monocytogenes strains to abiotic surfaces under cold stress. Front Microbiol 8: https://doi.org/10.3389/fmicb.2017.02221

Lemon KP, Higgins DE, Kolter R (2007) Flagellar motility is critical for Listeria monocytogenes biofilm formation. J Bacteriol 189:4418-4424.

https://doi.org/10.1128/JB.01967-06

Leriche V, Carpentier B (1995) Viable but nonculturable Salmonella Typhimurium in single- and binary-species biofilms in response to chlorine treatment. J Food Prot 58:1186-1191. https://doi.org/10.4315/0362-028x-58.11.1186

Liu S, Graham JE, Bigelow L, et al (2002) Identification of Listeria monocytogenes genes expressed in response to growth at low temperature. Appl Environ Microbiol 68:1697-1705. https://doi.org/10.1128/AEM.68.4.1697-1705.2002

Mereghetti L, Quentin R, Marquet-Van Der Mee N, Audurier A (2000) Low sensitivity of Listeria monocytogenes to quaternary ammonium compounds. Appl Environ Microbiol 66:5083-5086. https://doi.org/10.1128/AEM.66.11.5083-5086.2000

Page 6/9 
Minei CC, Gomes BC, Ratti RP, et al (2008) Influence of peroxyacetic acid and nisin and coculture with Enterococcus faecium on Listeria monocytogenes biofilm formation. J Food Prot 71:634-638. https://doi.org/10.4315/0362-028X-71.3.634

Miranda RO, Campos-Galvão MEM, Nero LA (2018) Expression of genes associated with stress conditions by Listeria monocytogenes in interaction with nisin producer Lactococcus lactis. Food Res Int 105:897-904. https://doi.org/10.1016/j.foodres.2017.12.030

Møretrø T, Langsrud S (2004) Listeria monocytogenes: biofilm formation and persistence in food-processing environments. Biofilms 1:107-121. https://doi.org/10.1017/s1479050504001322

Møretrø T, Schirmer BCT, Heir E, et al (2017) Tolerance to quaternary ammonium compound disinfectants may enhance growth of Listeria monocytogenes in the food industry. Int J Food Microbiol 241:215-224. https://doi.org/10.1016/j.ijfoodmicro.2016.10.025

Nowak J, Cruz CD, Tempelaars M, et al (2017) Persistent Listeria monocytogenes strains isolated from mussel production facilities form more biofilm but are not linked to specific genetic markers. Int J Food Microbiol 256:45-53. https://doi.org/10.1016/j.ijfoodmicro.2017.05.024

Orsi RH, Bakker HC de., Wiedmann M (2011) Listeria monocytogenes lineages: Genomics, evolution, ecology, and phenotypic characteristics. Int. J. Med. Microbiol. 301:79-96

Ortiz S, López V, Martínez-Suárez J V. (2014) Control of Listeria monocytogenes contamination in an Iberian pork processing plant and selection of benzalkonium chloride-resistant strains. Food Microbiol 39:81-88. https://doi.org/10.1016/j.fm.2013.11.007

Ouyang Y, Li J, Dong Y, et al (2012) Genome-wide screening of genes required for Listeria monocytogenes biofilm formation. J Biotech Res 4:13-25

Pieta L, Garcia FB, Riboldi GP, et al (2014) Transcriptional analysis of genes related to biofilm formation, stress-response, and virulence in Listeria monocytogenes strains grown at different temperatures. Ann Microbiol 64:1707-1714. https://doi.org/10.1007/s13213-014-0814-2

Poimenidou S V., Chrysadakou M, Tzakoniati A, et al (2016) Variability of Listeria monocytogenes strains in biofilm formation on stainless steel and polystyrene materials and resistance to peracetic acid and quaternary ammonium compounds. Int J Food Microbiol 237:164-171.

https://doi.org/10.1016/j.jjfoodmicro.2016.08.029

Radoshevich L, Cossart P (2018) Listeria monocytogenes: Towards a complete picture of its physiology and pathogenesis. Nat Rev Microbiol 16:32-46. https://doi.org/10.1038/nrmicro.2017.126

Riedel CU, Monk IR, Casey PG, et al (2009) AgrD-dependent quorum sensing affects biofilm formation, invasion, virulence and global gene expression profiles in Listeria monocytogenes. Mol Microbiol 71:1177-1189. https://doi.org/10.1111/j.1365-2958.2008.06589.x

Rieu A, Weidmann S, Garmyn D, et al (2007) agr system of Listeria monocytogenes EGD-e: Role in adherence and differential expression pattern. Appl Environ Microbiol 73:6125-6133. https://doi.org/10.1128/AEM.00608-07

Rodríguez-Melcón C, Capita R, Rodríguez-Jerez JJ, et al (2019) Effect of low doses of disinfectants on the biofilm-forming ability of Listeria monocytogenes. Foodborne Pathog Dis 16:262-268. https://doi.org/10.1089/fpd.2018.2472

Ryan S, Begley M, Hill C, Gahan CGM (2010) A five-gene stress survival islet (SSI-1) that contributes to the growth of Listeria monocytogenes in suboptimal conditions. J Appl Microbiol 109:984-995. https://doi.org/10.1111/j.1365-2672.2010.04726.x

Silva DAL, Camargo AC, Todorov SD, Nero LA (2017) Listeria spp. contamination in a butcher shop environment and Listeria monocytogenes adhesion ability and sensitivity to food-contact surface sanitizers. J Food Saf 37:e12313. https://doi.org/10.1111/jfs.12313

Silva DAL, Tavares RM, Nero LA (2020) Interference of sanitizers, $\mathrm{NaCl}$ and curing salts on Listeria monocytogenes adhesion and subsequent biofilm formation. Lett Appl Microbiol 71:438-443. https://doi.org/10.1111/lam.13374

Van Der Veen S, Moezelaar R, Abee T, Wells-Bennik MHJ (2008) The growth limits of a large number of Listeria monocytogenes strains at combinations of stresses show serotype- and niche-specific traits. J Appl Microbiol 105:1246-1258. https://doi.org/10.1111/j.1365-2672.2008.03873.x

Van Houdt R, Michiels CW (2010) Biofilm formation and the food industry, a focus on the bacterial outer surface. J. Appl. Microbiol. 109:1117-1131

Winkelströter LK, De Martinis ECP (2015) Different methods to quantify Listeria monocytogenes biofilms cells showed different profile in their viability. Brazilian J Microbiol 46:231-235. https://doi.org/10.1590/S1517-838220131071

Winkelströter LK, Gomes BC, Thomaz MRS, et al (2011) Lactobacillus sakei 1 and its bacteriocin influence adhesion of Listeria monocytogenes on stainless steel surface. Food Control 22:1404-1407. https://doi.org/10.1016/j.foodcont.2011.02.021

\section{Figures}




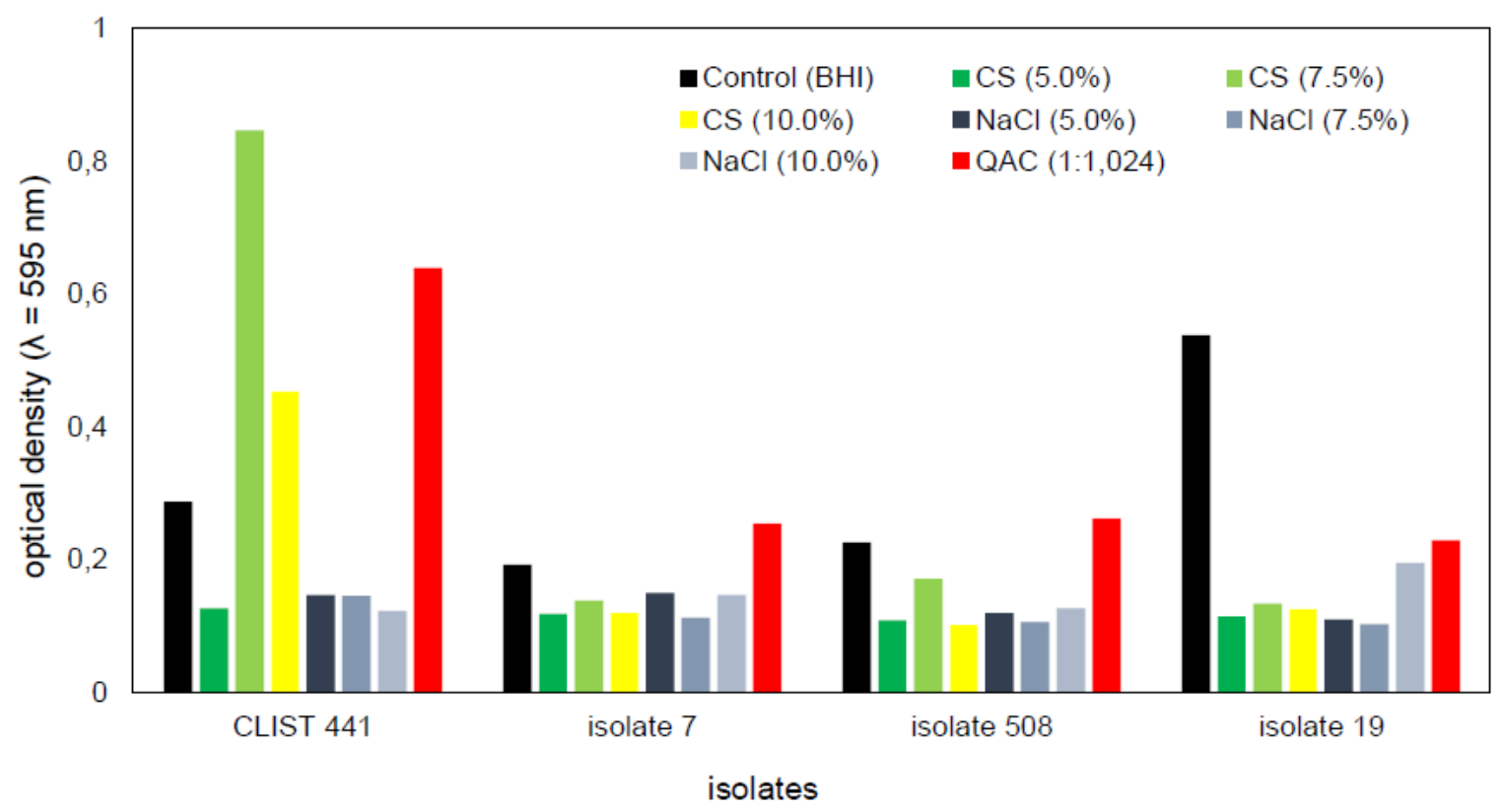

Figure 1

Absorbance values recorded for L. monocytogenes isolates subjected to adhesion assay in stainless-steel microtiter plates, after incubation at $37{ }^{\circ} \mathrm{C}$ for $72 \mathrm{~h}$. Bars indicate the treatments with different stressing conditions: Control (isolate alone, with brain heart infusion, $\mathrm{BHI}$ ), $\mathrm{Curing}$ salts (CS), $\mathrm{NaCl}$ and quaternary ammonium compound (QAC) based disinfectant.

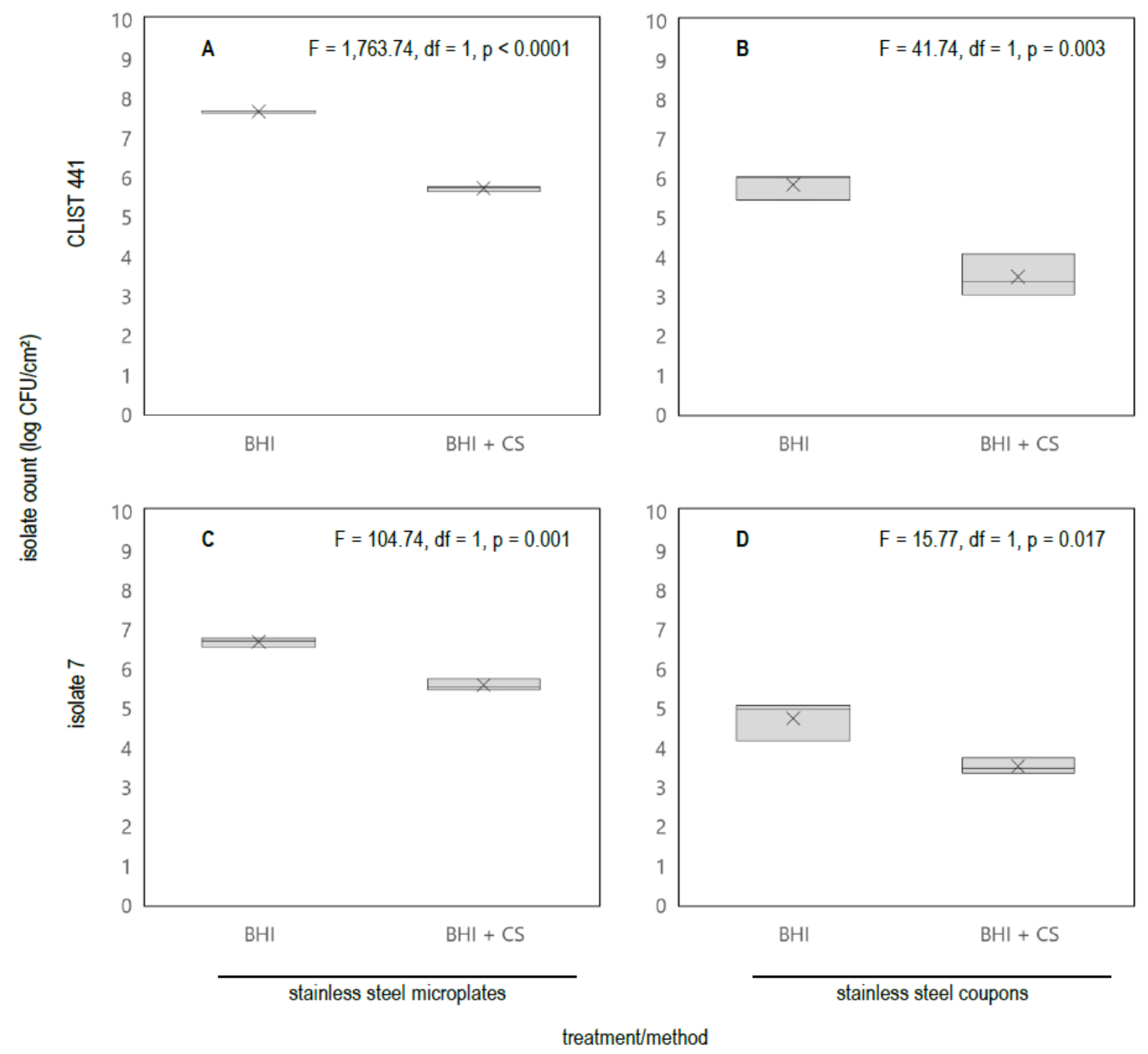

Figure 2 
Mean counts of L. monocytogenes isolates (lineage I) after biofilm forming assays (stainless-steel microplates and stainless-steel coupons) under specific stressing conditions. $\mathrm{BHI}$ : Control, using brain hearth infusion (BHI), $\mathrm{BHI}+\mathrm{CS}$ : $\mathrm{BHI}$ added with curing salt $(\mathrm{CS})$ at $7.5 \%(\mathrm{w} / \mathrm{v})$.

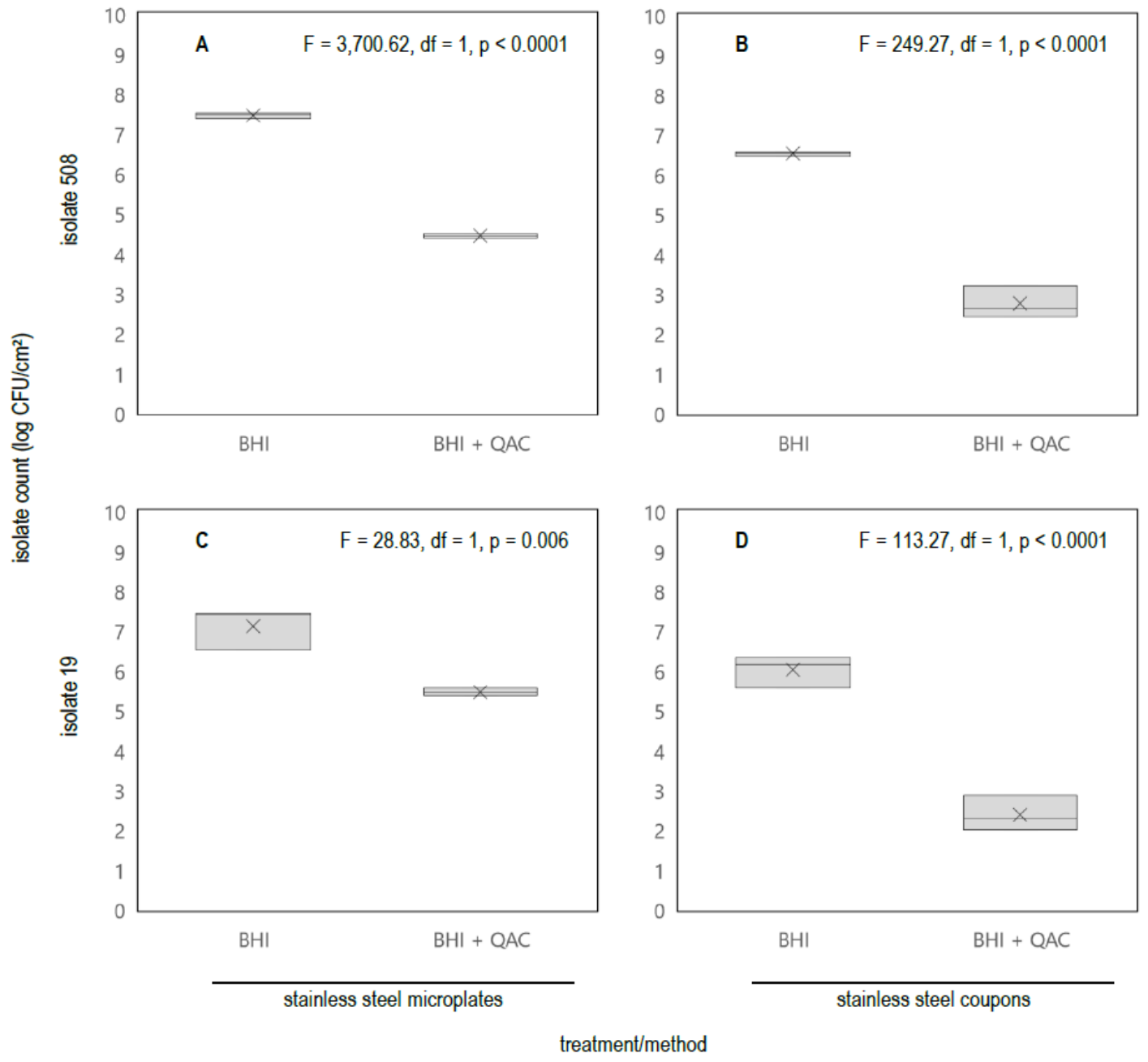

Figure 3

Mean counts of L. monocytogenes isolates (lineage II) after biofilm forming assays (stainless-steel microplates and stainless-steel coupons) under specific stressing conditions. BHI: Control, using brain hearth infusion (BHI), BHI + QAC: BHI added with quaternary ammonium compound (QAC) based disinfectant $(1: 1,024)$.

\section{Supplementary Files}

This is a list of supplementary files associated with this preprint. Click to download.

- 05SupplementaryTable20210329.docx 